\title{
A note on the effect of rare earth elements on the performance and thyroid hormone status of rearing piglets
}

\author{
D. Förster ${ }^{1}$, A. Berk ${ }^{1}$, H.O. Hoppen ${ }^{2}$, W.A. Rambeck ${ }^{3}$ \\ and G. Flachowsky ${ }^{1,4}$ \\ ${ }^{1}$ Institute of Animal Nutrition, Friedrich-Loeffler-Institute (FLI), \\ Ferderal Research Institute for Animal Health \\ Bundesallee 50, D-38116 Braunschweig, Germany \\ ${ }^{2}$ Institute for Food Toxicology and Chemical Analytics, University of Veterinary Medicine \\ Bischofsholer Damm 15, D-30173 Hannover, Germany \\ ${ }^{3}$ Ludwig-Maximilians-University, Faculty of Veterinary Medicine \\ Veterinärstr. 13, D-80539 Munich, Germany
}

(Received 5 March 2007; revised version 26 October 2007; accepted 15 January 2008)

\begin{abstract}
Rare earth elements (REE) have been used for decades in China to promote growth in plant production and farm animals. Studies are presently also being conducted under Western animal production conditions, however dose-response studies are relatively rare. In this study a total of 80 piglets were fed a diet supplemented with $0,100,200,400$ or $800 \mathrm{mg}$ of citrate-bound rare earth elements, consisting of, \%: lanthanum 30 , cerium 55 , praseodymium 5 and neodymium 10 . The trial lasted 35 days, the initial mean body weight of the piglets was $7.2 \mathrm{~kg}$. Apart from growth and feeding parameters, blood serum was analysed for $\mathrm{T}_{3}$ and $\mathrm{T}_{4}$ by radioimmunoassay (RIA). Feed intake decreased insignificantly with higher REE-levels. The daily weight gain of piglets amounted to 283 (control), 301 (100 mg), $254(200 \mathrm{mg}), 258(400 \mathrm{mg})$ and $271 \mathrm{~g}(800 \mathrm{mg})$. Thyroid hormone levels increased with REE-supplementation. More dose-response studies will be necessary to prove the effects of REE on growth parameters and their intermediate effects.
\end{abstract}

KEY WORDS: rare earth elements, growth, thyroid hormones, piglets

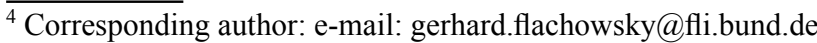




\section{INTRODUCTION}

The term rare earth elements (REE) encompasses the elements scandium, yttrium, lanthanum and the 14 chemical elements following lanthanum (order numbers 58-71) called lanthanides. REE have been used in China for decades in plant production and farm animal feeding to promote growth. Even under Western animal production conditions it has been reported that rare earth elements in the diet can improve animal growth performance significantly, as recently summarized by Redling (2006). Most of the experiments with piglets and pigs were carried out with dosages of between 100 and $300 \mathrm{mg}$ REE mixtures per kg feed (Redling, 2006). Higher growth rates were mostly accompanied by decreased thyroid hormone levels (Schuller et al., 2002; Knebel, 2004). Dose-response studies with higher levels have not been described in the literature. The aim of the present study was to investigate the effect of higher REE-dosages on feed intake, daily weight gain, feed efficiency and thyroid hormone concentration in piglets.

\section{MATERIAL AND METHODS}

A total of 80 hybrid ("BHZP") piglets (40 females/40 castrated males) were bought from a commercial breeder. The piglets were weaned at the age of 21 days with an average body weight (BW) of $7.2 \mathrm{~kg}$. In the Institute's stable they were divided into five groups, 4 piglets in 4 boxes, 16 piglets per group (Table 2) according their individual BW.

The animals in group 1 (control) were fed a cereal-soyabean meal based diet (Table 1). This diet was supplemented with 100, 200, 400 or $800 \mathrm{mg}$ (groups 2 to 5; Table 2) of citrate-bound rare earth elements consisting of, \%: lanthanum 30, cerium 55, praseodymium 5 and neodymium 10.

Table 1. Diet composition, \%

\begin{tabular}{lc}
\hline Ingredients & $\%$ \\
\hline Barley & 36.75 \\
Wheat & 30.00 \\
Maize, extruded & 7.50 \\
Soyabean meal & 15.00 \\
Soyabean concentrate & 4.00 \\
Soyabean oil & 2.50 \\
Premix & 3.00 \\
Amino acids & 1.25 \\
ME, MJ kg-1 DM, calculated & 15.39 \\
Crude protein, gkg ${ }^{-1} \mathrm{DM}$, analysed & 191 \\
\hline
\end{tabular}

${ }^{1}$ supplementation per kg mixed feed, IU: vit. A 12.000, vit. $\mathrm{D}_{3} 1.200$; g: Ca 7.35, P 1.8, Na 1.65; mg: $\mathrm{Mg} 300$, vit. E 36, vit. $\mathrm{B}_{1} 1.1$, vit. $\mathrm{B}_{2} 3$, vit. $\mathrm{B}_{6} 3$, vit. $\mathrm{K}_{3} 1.6$, nicotinic acid 15 , phantothenate 10 , choline chloride 150, Fe 120, Cu 30, Mn 60, Zn 120, I 1.5, Se 0.5, Co 0.6; $\mu$ g: vit. B 22 
Table 2. Experimental design

\begin{tabular}{lrrrrr}
\hline Group & 1 & 2 & \multicolumn{1}{c}{3} & \multicolumn{1}{c}{4} & \multicolumn{1}{c}{5} \\
\hline REE-supplementation, mg/kg & \multicolumn{1}{c}{-100} & 200 & 400 & 800 \\
Piglets & 16 & 16 & 16 & 16 & 16 \\
Boxes & 4 & 4 & 4 & 4 & 4 \\
Piglets per box & 4 & 4 & 4 & 4 & 4 \\
\hline
\end{tabular}

Diets were analysed for crude nutrients according to VDLUFA-guidelines (Bassler and Buchholz, 1993), and metabolizable energy content was calculated on the basis of GfE-recommendations (GfE, 2006). The use of REE-mixture premix with wheat is one of the most important problems when evaluating individual REE-effects. These naturally occurring mixtures are preferred due to their low cost compared with the pure substances.

The trial was designed as an one-period experiment with a duration of 35 days. Feed in mash form and water were offered ad libitum. The piglets were weighed weekly. Blood samples were taken from the vena cava cranialis after the first and the last trial weeks and the serum was analysed for thyroid hormones by specific radioimmunoassays. Triiodothyronine $\left(\mathrm{T}_{3}\right)$ was assayed using a commercial RIA kit ( $T_{3}$ RIA, DSL-3100, Diagnostic Systems Laboratories, Webster, Texas, USA), that had been validated for porcine serum. Sensitivity of the assay was $0.06 \mathrm{nmol} /$ 1, intra- and inter-assay c.v. were 5.9 and $4.7 \%$, respectively. Thyroxine $\left(\mathrm{T}_{4}\right)$ was assayed using a commercial RIA kit ( $\mathrm{T}_{4}$ RIA, DSL-3200, Diagnostic Systems Laboratories, Webster, Texas, USA), that had been validated for porcine serum. Sensitivity of the assay was $5.2 \mathrm{nmol} / \mathrm{l}$, intra- and inter-assay c.v. were 5.1 and $7.1 \%$, respectively.

Mean comparisons were conducted by multiple Student's t-test with the SAS (2002) univariate procedure.

\section{RESULTS AND DISCUSSION}

Growth performance. No disturbances in animal health were observed throughout the course of the experiment. The piglets in group 2 (100 mg REE kg-1) consumed insignificantly more feed than the animals of all other groups $(\mathrm{P}>0.05$; Table 3) and showed the highest daily weight gain (Table 3 ). The daily weight gain of piglets in group $2(100 \mathrm{mg}$ REE kg-1 $)$ was significantly higher $(\mathrm{P}<0.05)$ than those of group 3 ( $200 \mathrm{mg} \mathrm{REE} \mathrm{kg}^{-1}$ ), but did not show significant differences with any of the other treatments $(\mathrm{P}>0.05$; Table 3$)$. The animals in group 3 (200 $\mathrm{mg}$ REE $\mathrm{kg}^{-1}$ ) needed significantly more feed per kg weight gain than the piglets in all other groups $(\mathrm{P}<0.05$; Table 3$)$. 
Table 3. Animal performance in relation to REE-supplementation

\begin{tabular}{|c|c|c|c|c|c|}
\hline Groups & 1 & 2 & 3 & 4 & 5 \\
\hline REE mg kg-1 & - & 100 & 200 & 400 & 800 \\
\hline Initial body weight, $\mathrm{kg}$ & $7.2 \pm 1.0$ & $7.2 \pm 0.9$ & $7.2 \pm 0.9$ & $7.1 \pm 0.9$ & $7.1 \pm 0.8$ \\
\hline Final body weight, kg & $17.1^{\mathrm{ab}} \pm 2.2$ & $17.7^{\mathrm{a}} \pm 3.1$ & $15.6^{\mathrm{b}} \pm 3.9$ & $16.2^{\mathrm{ab}} \pm 1.5$ & $16.4^{\mathrm{ab}} \pm 2.9$ \\
\hline Feed intake, $\mathrm{g} \mathrm{day}^{-1}$ & $467 \pm 39$ & $494 \pm 61$ & $461 \pm 52$ & $447 \pm 33$ & $433 \pm 44$ \\
\hline Daily weight gain, $g$ & $283^{\mathrm{ab}} \pm 47$ & $301^{\mathrm{ab}} \pm 65$ & $243^{\mathrm{b}} \pm 101$ & $258^{\mathrm{ab}} \pm 34$ & $265^{\mathrm{ab}} \pm 71$ \\
\hline Feed conversion ratio, $\mathrm{kg} \mathrm{kg}^{-1}$ & $1.67^{b} \pm 0.09$ & $1.64^{b} \pm 0.15$ & $1.93^{\mathrm{a}} \pm 0.13$ & $1.74^{b} \pm 0.10$ & $1.64^{b} \pm 0.04$ \\
\hline
\end{tabular}

Similarly to the Chinese experiments (see Redling, 2006) the effects of low doses of REE (up to $300 \mathrm{mg} / \mathrm{kg}$ ) on weight gain of piglets have been described in the literature (Rambeck et al., 1999; He et al., 2001; Borger, 2003; Knebel, 2004). In some cases, DWG increased by up to $22.5 \%$ (He et al., 2001; Knebel, 2004 ) and feed conversion improved by up to $11 \%$. In agreement with a recent study by Kratz et al. (2006) the present study did not show such significant effects. Supplementation of $200 \mathrm{mg}$ REE or more decreased feed intake and showed lower DWG than control animals or piglets supplemented with $100 \mathrm{mg}$ REE per $\mathrm{kg}$ (Table 3). Reasons for such large differences between various authors could not be explained and need further clarification.

Thyroid hormones. Thyroid hormone concentrations in blood serum decreased after five weeks of experimentation in comparison with one week in all groups (Table 4). Apart from the $\mathrm{T}_{3}$-concentration after one week, thyroid

Table 4. Influence of REE-supplementation on thyroid hormones in serum of piglets, $n m o l \cdot l^{-1}(n=4)$

\begin{tabular}{lcccc}
\hline Experiment of week & \multicolumn{3}{c}{$1^{\text {st }}$} & \multicolumn{2}{c}{$5^{\text {th }}$} \\
\cline { 2 - 5 } Group, dosage, $\mathrm{mg} \mathrm{kg}^{-1}$ & \multicolumn{1}{c}{$\mathrm{T}_{4}$} & $\mathrm{~T}_{3}$ & $\mathrm{~T}_{4}$ & $\mathrm{~T}_{3}$ \\
\hline $1(0)$ & $57.6 \pm 5.9$ & $1.27^{\mathrm{bc}} \pm 0.53$ & $35.7 \pm 3.4$ & $0.73 \pm 0.14$ \\
$2(100)$ & $56.0 \pm 9.4$ & $0.85^{\mathrm{c}} \pm 0.16$ & $42.2 \pm 3.8$ & $1.20 \pm 0.21$ \\
$3(200)$ & $60.9 \pm 5.5$ & $1.49^{\mathrm{b}} \pm 0.21$ & $42.8 \pm 6.2$ & $1.16 \pm 0.64$ \\
$4(400)$ & $57.0 \pm 7.4$ & $1.00^{\mathrm{bc}} \pm 0.24$ & $42.2 \pm 2.8$ & $1.20 \pm 0.25$ \\
$5(800)$ & $52.2 \pm 13.3$ & $2.09^{\mathrm{a}} \pm 0.35$ & $41.2 \pm 7.3$ & $1.31 \pm 0.53$ \\
\hline
\end{tabular}

a,b different letters in one column show significant differences $(\mathrm{P}<0.05)$

hormones did not show significant differences $(\mathrm{P}>0.05)$ between treatments. The combination of low sample numbers $(n=4)$ and the high variability within groups precludes an interpretation of these data (Table 4). Lower T3- and T4concentrations in older piglets were also observed by Carroll et al. (1998) and Tarn et al. (1998).

Atpresent, theeffects of REE-supplementation on thyroidhormone concentration are not clear. Contrary to the present study, thyroid hormone concentrations have been shown to decrease with higher animal performances in some cases (He et al., 
2001; Schuller et al., 2002; Eisele, 2003). It has to be considered that these studies can only be compared to a limited extent. The concentrations of thyroid hormones may be influenced by a variety of factors, such as the age of the animals, feeding procedures, REE-concentrations and the relationship between feeding time and the time of blood collection.

In conclusion, further studies are necessary to understand the mode of action of supplemented rare earth elements.

\section{REFERENCES}

Bassler R., Buchholz H., 1993. Die chemische Untersuchung von Futtermitteln, Band II. VDLUFAVerlag, Darmstadt

Borger C., 2003. Alternative Methoden in der Schweinemast. Untersuchungen zum leistungssteigernden Potential Seltener Erden und zur Jodanreicherung im Gewebe durch die Verfütterung von Meeresalgen. Diss. Ludwig-Maximilians-Universität, München

Carroll J.A., Veum T.L., Matteri R.L., 1998. Endocrine responses to weaning and changes in postweaning diet in the young pig. Domest. Anim. Endocrinol. 15, 183-194

Eisele N., 2003. Untersuchungen zum Einsatz Seltener Erden als Leistungsförderer beim Schwein. Diss. Ludwig-Maximilians-Universität München

GfE, 2006. Empfehlungen zur Energie- und Nährstoffversorgung von Schweinen. DLG-Verlag, Frankfurt/Main, pp. 247

He M.L., Ranz D., Rambeck W.A., 2001. Study on performance enhancing effect of rare earth elements in growing and fattening pigs. J. Anim. Physiol. Anim. Nutr. 85, 263-270

Knebel C., 2004. Untersuchungen zum Einfluss Seltener Erd-Citrate auf Leistungsparameter beim Schwein und die ruminale Fermentation im künstlichen Pansen (RUSITEC). Diss. LudwigMaximilians-Universität München

Kraatz M., Taras D., Männer K., Simon O., 2006. Weaning pig performance and faecal microbiota with and without in-feed addition of rare earth elements. J. Anim. Physiol. Anim. Nutr. 90, 361 368

Rambeck W.A., He M.L., Chang J., Arnold R., Henkelmann R., Süss A., 1999. Possible role of rare earth elements as growth promoters. In: Vitamine und Zusatzstoffe in der Ernährung von Mensch und Tier, 7. Symposium. Jena (Germany), pp. 311-317

Redling K., 2006. Rare earth elements in agriculture with emphasis on animal husbandry. Diss. Ludwig-Maximilians-Universität, München

Schuller S., Borger C., He M.L., Henkelmann R., Jadamus A., Simon O., Rambeck W., 2002. Untersuchungen zur Wirkung von Seltenen Erden als mögliche Alternative zu Leistungsförderern bei Schweinen und Geflügel. Berl. Mün. Tierärztl. Wochenschr. 115, 16-23

Tarn C.Y., Rosenkrans Jr. C.F., Apple J.K., Kirby J.D., 1998. Effects of 6-N-propyl-2-thiouracil on growth, hormonal profiles, carcass and reproductive traits of boars. Anim. Reprod. Sci. 50, $81-94$ 